\title{
Robotic Internal Audit - Control Methods in the Selected Company
}

\author{
Marcela Hradecká \\ Department of Accounting and Finances, Faculty of Economics, University of South Bohemia in Czech \\ Budejovice, Czech Republic
}

\begin{abstract}
Simultaneously with the gradual introduction of automation and robotics industry 4.0., it is necessary to apply and use control methods of internal audit. Robotics and automation now provide us with far greater scope for applying internal audit control methods. Especially in manufacturing and agriculturals businesses is data interoperability important to streamline the production process and save operating costs. With proper application of checkpoints at risk points, hard data can be retrieved to prevent losses or fraud .

Using internal audit control methods, it is possible in real time to gain an overview of the company's situation and to contribute to better decision making by the management or the owners of the company. The article focuses on the implementation of robotic internal audit in the process of industrial beer production. The main goal is to elaborate own methodology for management of production or agricultural company within informatics and accounting to reduce high production and operating expenses.
\end{abstract}

\section{Keywords}

Internal audit, fraud, IoT, Industry 4.0, manufacturing company, agricultural businesses, accounting, interoperability.

Hradecká, M. (2019) "Robotic Internal Audit - Control Methods in the Selected Company", AGRIS on-line Papers in Economics and Informatics, Vol. 11, No. 2, pp. 31-42. ISSN 1804-1930. DOI 10.7160/aol.2019.110204.

\section{Introduction}

The company management is the very sophisticated system (Kavan, 2002) of methods that is applied by top management, eventually by owners and investors as the effective instrument for the company strategy, planning and operating savings in the production process. The fraud management also has its irreplaceable place in the modern system of the company management and in its top management. The task of the fraud management is the elimination of all losses caused by failure of the human factor using robotization, automation and especially digitisation.

Managers monitor these processes and take measures based on obtained data through the robotic internal audit ${ }^{1}$ that lead to a reduction of losses in the company ${ }^{2}$. This problem is addressed also by agricultural businesses that

\footnotetext{
${ }^{1}$ Internal audit can be understood as internal control procedures used to secure assets and ensure the accuracy and reliability of accounting data. Danos et al. (1992).

2 Risk management in a business includes three basic rules that allow risks to be eliminated. 1. Don't risk more than you can lose. 2. Consider probabilities. 3. Don't risk much for little. Smejkal and Rais (2013).
}

produce commodities for the food industry.

Automation and progressively robotization of agriculture and food industry began in the $20^{\text {th }}$ century. The strategic idea was to eliminate hard (Grimstad et al., 2015) and physically demanding human work, especially during harvests. Robotic machines and systems have also penetrated into the field of automated robotic milking, stable cleaning (Kabeš, 2015), fruit harvesting, vine, etc. An important aspect is the compliance of robotic systems with the requirements of farm management. In particular, these include the reduction of operating expenses, human labor saving, time saving and return on invested capital. Agriculture robotization is closely linked to robotics introduced in the food industry. In some areas, the cultivation of agricultural commodities is intertwined with food industry. A brewery can be mentioned as an example. The cultivation of malting barley, which is the main raw material in beer production, is fully included in agricultural activity. Another intermediate step is malting for malt production. Malting can perform farms as part of their activity, as well as breweries that are included in the food sector. 
The main problem of managing an agricultural or food enterprise today is the many actions, both manual and administrative, carried out by employees with different human factors. The operations are carried out in accordance with the company's internal guidelines, but without control links to the enterprise information system. There may be opportunities for fraud during the process of purchasing inputs into production and during the production process itself. Control activities are performed only on the basis of current monthly financial statements when the management of a company can only say that the production of a given product was loss-making and it is difficult to decipher why the cost of production was so high.

Literature research on robotic internal audit as methods of control for the prevention of fraud in accounting and production have not been found by the author in her research. Generally Robotic Process Automation (RPA) deal auditors in their article PwC (RPA Robotic Process Automation, 2017). They present the possibilities of using software robots in processing receivables, entering data between applications, copying, etc. Another company that generally deals with Robotic process automation (RPA) is KPMG (RPA Internal Audit and Robotic Process Automation, 2018). The company's auditors state that RPAs will help identifyopportunities for theintegration ofautomated assets and thus influence business processes and functions. Authors Dovenport and Raphael (2018) also dealt with automated audit processes. In this article, they provide options for replacing manual audits with automated processes.

Main goals:

1. Detection of risk spots at various stages of production to identify fraud opportunities

2. Review the manufacturing process to reduce production and operating costs

3. Implementation of Robotic Internal Audit IT application to ensure interoperability of production data and enterprise information system

For the application of control methods of the robotic internal audit ${ }^{3}$ was selected production company, whose object of activity is the beer production and its bottling into PET bottles.

In a selected food enterprise, detection was carried

\footnotetext{
3 Ř́movská (2001) states that internal audit helps the company achieve its goals and introduces a systematic approach to assessing and improving the effectiveness of risk management, management and control processes.
}

out an existing process $^{4}$ procedures. Based on the conclusions of this analysis, was presented to the management of the company a detailed report on the status of processes in the enterprise.

In particular, this report states that the current technology for brewing beer is unsatisfactory, namely for wear and tear, that is, production losses such as leakage of some equipment, high energy and water consumption, non-ecological, as well as obsolescence from the perspective of IT technology. Individual devices are controlled only by the start and stop buttons or manually. The production equipment does not communicate with the superior information system at all. It is not possible to obtain any important data from the existing technology for operational and strategic management decisions.

Based on the conclusions and recommendations of this detailed report, the owners of this manufacturing company decided to purchase modern technology that meets requirements of the 4.0 industry. One of the reason for the purchase of this technology, is to eliminate all opportunities and possibilities of frauds that provably occur at all production companies with the object of beer industry activity in the Czech Republic that use the technology with a large portion of human work.

\section{Materials and methods}

- Description of new technology for beer production - scheme

- Risk point analysis in term of fraud-scheme

- Design and implement control devices in the enterprise process system

- Proposal for implementation of supportive control methods

- A proposal for the implementation of a robotic internal audit software application by a IT engineer (project team member) to ensure interoperability

- Comparison of original and new technology data

- Induction of operating and production cost savings

- Evaluation of targets

At the stage of processing procedures and proposals, the author based her work on the literature review. The first two methods, description and analysis of the new technology material extracted

\footnotetext{
${ }^{4}$ Risk management focuses mainly on monitoring activities (risk detection) and subsequent prevention of fraud and theft. (Korecký and Trkovský, 2011).
} 
from a foreign internship was used. As part of a collaboration with Marco Bortolan, the author designed a system of checkpoints and control devices indicated in the scheme. (Figure 1).

Control and supporting methods applied for individual phases of the production process.

The activity of fraud management starts during planning of the purchase of production commodities using anti-corruption procedures for the selection of suppliers. These procedures are supported by information technologies. Deliveries of individual commodities to the warehouse precede the dispatch of labels to suppliers. The label includes the following data: the commodity name, commodity trademark, weight of the commodity with packaging, commodity net weight, expiration time of the commodity, number of the stock item, barcode. Then the supplier physically accepts it into the warehouse and hands over the accompanying documents required by the legislation and documents required by the company's procedure, as well as registers the commodity as a warehouse item by reading the barcode on a reader located at a single entry into the warehouse. In the initial phase of production, i.e. in bins, the individual commodities are re-stamped by reading the barcode. The bins are multiples of the weight of the commodity packaging and are provided with a weighting system. The next brewing process is already fully automated and works without human factor intervention, only based on a recipe stored in the central counter. The production phase after beer brewing continues by placing the beer in the matured tanks for the ripening process. The further production phase is bottling of beer into PET bottles. The process of beer bottling into PET bottles is carried out using an intelligent, fully automatic batch line consisting of individual machines and devices that operate as one synchronous unit ending with a palletizer. The production process ends with the result that the boiled ripe beer is bottled in PET bottles. The bottles are labelled, packed in a group pack, placed on a euro pallet wrapped in a foil wrapping and provided with a barcode label. The whole euro pallet is then placed in the warehouse by reading the barcode on the label.

\section{Supporting methods}

Supporting methods serve as complementary methods to the robotic internal audit. The supporting methods used in this selected company are: camera system, attendance system, physical security, physical control activity by documentary and material worker according to responsibility, monitoring the observance of work activities by the responsible persons. Among the support activities, the selection of employees can be included when recruiting staff by the human resources department. The camera system in the selected company monitors in real time all events where the risk of fraud is increased. The camera system monitors the surroundings of the production company as well as the interior production facilities. The specific risk points are: commodities take-over activities to the warehouse, dispatch of commodities from the warehouse of raw materials, the storage of the finished products in the warehouse. Records and archived data from camera systems are used by internal audit for secondary analysis when discrepancies

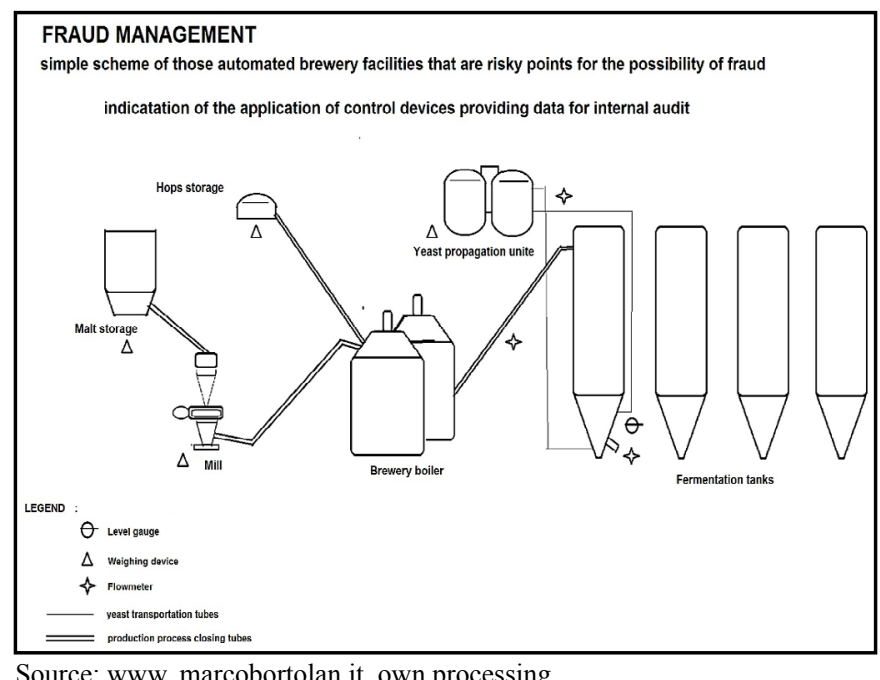

Source: www. marcobortolan.it, own processing

Figure 1: Automatic devices of the brewery. 
in values of the company system are detected. This means finding out the different values reported by the commodity purchase department, commodity stocks and financial accounting. This supporting method prevents the thefts of entry commodities and finished products and thefts can be detected at a given moment. Another closely related supporting method is the physical security. Its intention is the psychological stimulus "I will be caught in the act." That means to discourage the temptation to alienate the property or commodities owned by the company. The attendance system as the supporting method fulfils a number of supporting tasks. The attendance for wage purposes is the most important one. The attendance system provides a periodic report of the number of worked hours, both regular and overtime. Another important task is an overview of persons who are situated in a production facility in a given time period. This means finding out that there are also non-shift workers in the production facility. For internal audit purposes, the attendance system provides data to analyse the production efficiency, respectively a share (combining) of functions, because the modern and fully automatic beer brewing plant with the fully automatic beer bottling line into PET bottles allows this sharing. The periodic physical and document control as the internal audit supporting method enables to physically check the status of entry commodities or finished products with accompanying documents on the purchase of material commodities. For example, a check of delivery notes, shipping notes, invoices with warehouse receipts and release orders or check of -ups of stacked material commodities with data from labels issued by the purchase department. Data from the results of physical and documentary checks are very valuable for internal audit purposes. Together with other supporting methods, they help to prevent thefts and frauds of entry commodities when purchasing commodities or stealing finished products from the warehouse.

Monitoring of observance of work activities is one of the other supporting activities. It is done by a responsible worker and its aim is a psychological incentive for workers to move only at their workplace. This supporting method helps to discourage the temptation to alienate the property of the company and at the same time helps to keep the production process flowing within the work shift. So there is no production downtime such as failure to add labels, closing caps, packaging foils, etc. The optional supporting method is the selection of employees by the human resource department.
Every company should consider behavioural influences in the selection procedures for new job positions in the company. Job candidates are interviewed in multiple-stage selection procedures and in many cases with psychological tests, for example a BMTI personal test (Myers Brigs, 1980). This test can reveal the tendencies of individual types of personality to mistakes, such as distraction, but also the tendency to thefts and frauds.

The robotic internal audit control methods are a set of financial and non-financial values and information obtained through reported data from information systems $s^{5}$ in the real time as well as from datastored in the datastorage "data warehouse" The control methods used in this selected company are: binding internal strategic purchasing procedure, measuring of quantities, binding procedure of the sales department. The first mentioned method - binding internal strategic purchasing procedure especially includes these obligations: a selection of suppliers from as many potential candidates as possible. Registered candidates must be inspected for their creditworthiness and stability in order to avoid bankruptcy of the supplier during any cooperation. To communicate with suppliers, you only need to use e-mail company correspondence. The personal contact with the supplier is only possible after a meeting planned in advance and with the participation of at least two persons. After each negotiation with the supplier, a record of this meeting is made, with which all participated parties are acquainted. This record is required to be stored on the intranet and made available to internal audit workers. The telephone communication is inadmissible at the conclusion of the contract. Every supplier must respect the binding strategic purchasing procedure and fulfil the obligations that arise for him /her as a supplier. These obligations also include the provision of the supplied commodity with labels issued by the purchase department of the production company. This control method leads to the prevention of the corrupt environment when purchasing input commodities. The most important control methods include the measurement of quantities.

\footnotetext{
${ }^{5}$ Král et al. (2008) states that every decision is original and its information support is specific. The decision-making information system is more demanding than just providing the basis for comparing the reality with the desired state.

${ }^{6}$ Pospíšilová et al. (2008) states that data warehouses are a suitable superstructure for transformation systems, through which information can be easily obtained for summary data analysis and for uncovering hidden connections.
} 
The technical devices for measuring of quantities used in this production company are: barcode scanners, technological scales, level gauges and flowmeters. The barcode scanners measure a number of commodity packages of a given weight stored in the commodity warehouse. The quantity of the commodity is thus automatically recorded on the commodity storage card of the economic system of the company. For purposes of the internal audit, the barcode scanners provide the data on the stacked quantity of the commodity for the control comparisons of stocks between the warehouse and financial accounting. In case of inconsistencies, the secondary data and records from camera (CCTV) systems shall be used. This control method prevents the theft of input commodities. Further technical devices are technological scales. These devices measure a weight of the commodity in bins and further a raw material modified by milling in the mill. For purposes of the internal audit, the control technological scales provide data on the quantity of the commodity taken out from the warehouse and placed into the bin in front of the mill for the control comparations of stocks between the warehouse, bin before the mill and financial accounting. In case of inconsistencies, secondary data and records from camera (CCTV) systems are used. This control method prevents the thefts of input commodities. The importance of placing the technological weighing scales under the mill is to control the amount of input raw material treated by milling into the beer brewing process according to a calculated recipe. The technological weighing scales are further placed under the hop bin for the check of the amount of input raw material to the production according to a calculated recipe. For internal audit purposes, these technological weighing scales placed under the mill room and hop bin provide data for the check of compliance with production calculations and determination of variations on the given batch. In the case of yeast propagators, the technological weighing scales fulfil the control safety function to prevent the theft of the very valuable input commodity. Other closely related devices with technological weighing scales are flowmeters located on the yeast propagator and on the pipeline between the brewing plant and fermenting tanks. This device measures the amount of liters of brewed beer pumped from the brewing plant into the fermenting tanks and the amount of added yeast from the yeast propagator. For internal audit purposes, these flowmeters provide data for checking of compliance with production calculations and determining of deviations in the fermentation process. Level gauges measure the level of beer in the fermenting tanks. For internal audit purposes, they provide data on the amount of beer placed in tanks. The level gauges as control devices placed on the fermenting tanks fulfil a safety function to prevent beer and yeast thefts. In the beer production process, this place is considered to be the most critical in terms of fraud management. The next phase of a fully automated production plant is beer bottling into PET bottles.

In order to efficiently perform the bottling line as a set of machines and equipment aggregated into one automated functional system, we serve a wide range of control devices for the proper performance of individual bottling line operations (bottling, closing, labelling, packing). These measuring devices provide data for the amount of filled beer into PET bottles for internal audit purposes. The filling device is able to provide data on the number of well-filled bottles, the number of filled bottles per unit of time, the number of bottles not filled. The labelling device provides data on labelled bottles and not on unlabeled bottles. The packing unit provides data on the number of packed bottles in the group pack. The palletizer provides data on the number of individual packages placed on the pallet. Reported data from the filling line for internal audit purposes serves to compare the number of bottles coming out from the bottling device and coming out from the labelling device. Another function of these control devices is also the safety aspect to avoid thefts of bottled beer. In case of discrepancies, secondary data from the camera system can be used. Packages placed on the pallet are labelled with a barcode label. At the goods warehouse entry, the pallets are registered into the company's economic system by scanning of the bar code with the scanner. The benefits of the barcode scanner control method are described in the previous paragraphs. The last control method is the binding internal procedure of the sales department. It particularly includes the following duties: monitoring of the compliance with the pricing policy for clients at all levels, observance of the anticorruption internal company policy. All extra discounts and non-standard sales conditions provided to customers must be discussed and approved in advance by an authorized manager, most often by a financial director. Employees of the Sales Department are banned from all business activities, and every year they submit 
schedules of assets (property returns) according to the procedure with which they were acquainted with the entry into employment.

\section{Internal audit - robotic system}

More and more company managers are interested in promoted robotic software that automates manual processes, makes employees work more effectively and provides the time to focus on methods, how to increase revenues and reduce costs. The Departments of Internal Audits in the Czech business environment are in the early stages of understanding how the robotics can support the automation of the company's internal processes. In fact, only about $10 \%$ of companies and their audit teams plan to use automated and robotic processes in this year. Approximately $80 \%$ of companies do not plan to use RPA at all (RPA Robotic Process Automation, (2017).

It is necessary to note that the present managers of the Internal Audit Departments have not done much in the field of service sharing. They show their interest in information about robotic internal audits, but they still have a lack of professional knowledge and experience needed for implementation of this project into the production company process.

What is the robotic software?

The robotic software is basically what separates it from other forms of automation. This means that it is not intended for any process or activity. The robotic software is flexible and can be almost used by any rule-based activity. It reminds of human interaction with IT systems.
Unlike a human factor, the robotic software can run rules-based steps for a fraction of the time a person needs to do this. RPA is the software that can record multiple steps among more systems (Figure 2).

Multi-step recording between multiple systems is important for program data interchange, such as OPCUA, OPC, MODBUS / TCP, PROFINET, AJAX, SOAP. Internet Object Technology "IoT" - 4.0 industry allows the collection and integration of the operational data of all machinery present in the production company into a single control platform that provides continuous monitoring of the production company's efficiency level performance in a real-time environment and allows the remote access to all decentralized locations in case of inconsistencies or problems. In this way, it is possible to obtain real-time information, either from an aggregated point of view of the entire production line of the company (production volume, average production time, consumption, waste and stock) or from the viewpoint of each individual machine. An example of such a software application is the corporation SMI Group's new application for automation and control "SWM Supervisor" (IFI Intelligent factory of 4.0 industry, 2018). The "SMI" application was developed according to principles of Industry 4.0 and IoT (Internet of Things - called in informatics as the network of physical devices, appliances and other devices that are equipped with electronics, software, sensors, moving parts or network connectivity to enable these devices to interconnect and exchange data). IoT allows you to combine typical functions of collecting and monitoring the production data from a series of machines that simplify the device control,

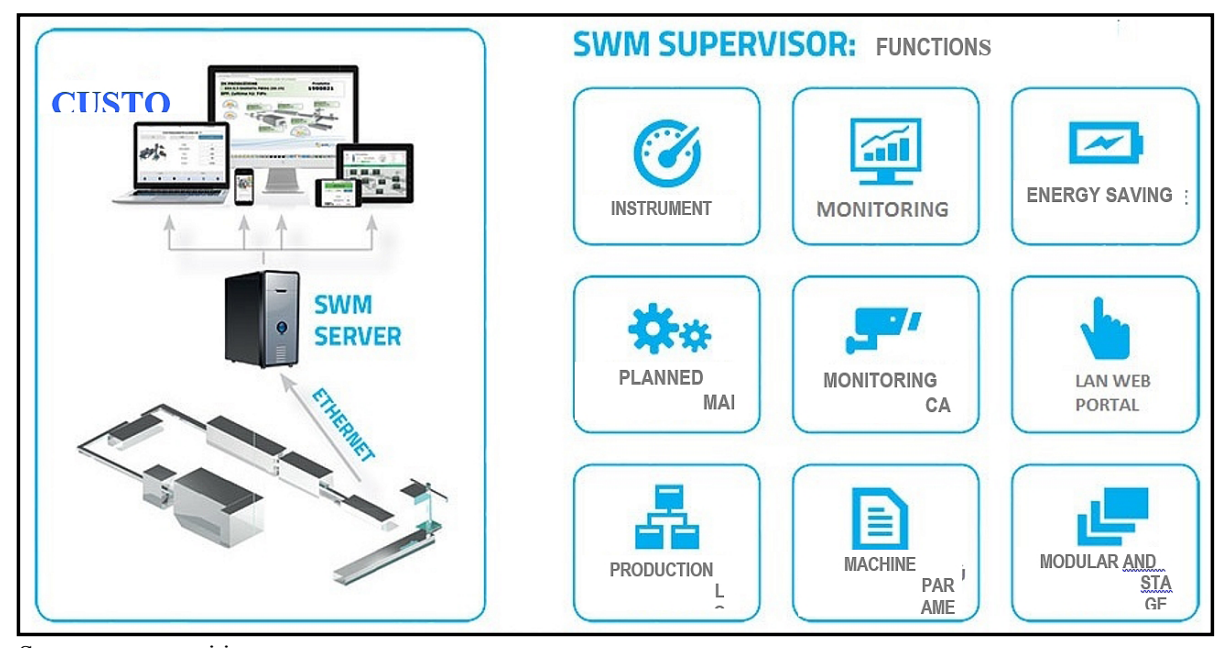

Source: www.smi.it

Figure 2: Intelligent factory of 4.0 industry. 
increase its productivity, safety and reduce operating costs, ensuring the excellent return on investment. The SWM Supervisor is based on a modular, open and flexible "company" web portal that can be customized to any application area and is available at several levels to meet the needs of all data collection and surveillance. Thanks to this innovative SMI system, it is easy to identify the main causes of downtime of the bottling or packing line, to improve the overall line efficiency and to reduce the time required for machine maintenance on the production line and format changes. It is also possible to obtain a structured report for performing of analyses with various functions, such as backgrounds for the internal audit.

\section{Own contribution}

- $\quad$ Presenting the management of the business corporation, for what purpose and in what way it is possible to use the extracted data from the software application in real time.

- Development of author's own proposal of RPA implementation methodology and own participation in RPA implementation.

The collection of these valuable data shall also serve as prevention against thefts, which the food production companies in the Czech Republic are constantly facing. It especially concerns attractive foodstuffs such as alcohol, beer, chocolate, etc. By collecting and distributing of information sent through various intelligent devices located in the production line and connected to the network it is possible to easily manage and transfer data through the web so they can be shared instantly with people, systems and other IT applications, both on the Internet and on the company intranet. By integrating the SWM Supervisor with the SMI Group, together with the software of robotic and automated storage of finished products, comprehensive data on needed quantities can be obtained from the beginning of the production process up to the expedition in the production factory. These valuable data lead to financial savings, better and more efficient decision-making and, last but not least, to prevent unintentional and criminal losses. So this avoids frauds in accounting and distortions of profit. For each production or farm, it is necessary to create a specific software application within the RPA project according to the client's requirements so that he can respond to the situation immediately.

\section{Comparison of energy consumption old and new technology}

By comparing the energy requirements of old and new brewing technology, the author came to the conclusion that the new technology is up to $46.5 \%$ more economical (Table 1).

\begin{tabular}{|l|r|l|c|}
\hline Old equipment & KW & New equipment & KW \\
\hline Brewhouse & 40 & Brewhouse & 24 \\
\hline Yeast propagator & 8 & Yeast propagator & 3 \\
\hline Ice water tank & 35 & Ice water tank & 24 \\
\hline Hot water tank & 9 & Hot water tank & 6 \\
\hline Steam generator & 4 & Steam generator & 2,5 \\
\hline Fermantation tanks & 10 & Fermantation tanks & 8 \\
\hline Open maturation room & 40 & Maturation tanks & 8 \\
\hline Mill & 10 & Mill & 8 \\
\hline Total & 156 & Total & 83.5 \\
\hline
\end{tabular}

Source: author's processing

Table1: Beer processing technology.

By comparing the energy intensity of old and new beer bottling technology to PET bottles, the author concluded that the new technology is $27.48 \%$ more economical (Table 2).

\begin{tabular}{|l|r|l|c|}
\hline Old equipment & KW & New equipment & KW \\
\hline Depaletisation & 15 & Depaletisation & 10 \\
\hline Filling block & 19 & Filling block & 15 \\
\hline Dryer & 30 & Dryer & 14 \\
\hline Pastorisation unit & 50 & Pastorisation unit & 30 \\
\hline Conveyors & 30 & Conveyors & 28 \\
\hline Packaging machine & 60 & Packaging machine & 55 \\
\hline Paletisation unite & 10 & Paletisation unite & 5 \\
\hline Stretchwrapper & 8 & Stretchwrapper & 4 \\
\hline Total & 222 & Total & 161 \\
\hline
\end{tabular}

Source: author's processing

Table 2: Beer bottling.

Comparison of personal employment of technology operations old and new technology

By comparing the personnel intensity of old and new beer technology, the author came to the conclusion that the new technology requires 6 employees less than old technology (Table 3). 


\begin{tabular}{|l|c|l|c|}
\hline Old equipment & $\begin{array}{c}\text { No. } \\
\text { empl }\end{array}$ & New equipment & $\begin{array}{c}\text { No. } \\
\text { empl }\end{array}$ \\
\hline Brewhouse & 2 & Brewhouse & 1 \\
\hline Yeast propagator & 1 & Yeast propagator & 0 \\
\hline Ice water tank & 1 & Ice water tank & 0 \\
\hline Hot water tank & 0 & Hot water tank & 0 \\
\hline Steam generator & 0 & Steam generator & 0 \\
\hline Fermantation tanks & 0 & Fermantation tanks & 0 \\
\hline Open maturation room & 1 & Maturation tanks & 0 \\
\hline Mill & 2 & Mill & 0 \\
\hline Total & 7 & Total & 1 \\
\hline
\end{tabular}

Source: author's processing

Table 3: Beer production.

By comparing the personnel demands of the old and the new technology of beer bottling, the author came to the conclusion that the new technology requires 7 employees than old technology (Table 4).

\begin{tabular}{|l|c|l|c|}
\hline Old equipment & $\begin{array}{c}\text { No. } \\
\text { empl }\end{array}$ & New equipment & $\begin{array}{c}\text { No. } \\
\text { empl }\end{array}$ \\
\hline Depaletisation & 1 & Depaletisation & 0 \\
\hline Filling block & 1 & Filling block & 2 \\
\hline Dryer & 0 & Dryer & 0 \\
\hline Pastorisation unit & 1 & Pastorisation unit & 0 \\
\hline Conveyors & 0 & Conveyors & 0 \\
\hline Packaging machine & 1 & Packaging machine & 0 \\
\hline Paletisation unite & 4 & Paletisation unite & 0 \\
\hline Stretchwrapper & 1 & Stretchwrapper & 0 \\
\hline Total & 9 & Total & 2 \\
\hline
\end{tabular}

Source: author's processing

Table 4: Beer bottling.

By comparing the other personnel demands of the old and the new technology, the author came to the conclusion that the new technology requires less staffing of 12 employees (Table 5).

\begin{tabular}{|l|c|l|c|}
\hline Old equipment & $\begin{array}{c}\text { No. } \\
\text { empl }\end{array}$ & New equipment & $\begin{array}{c}\text { No. } \\
\text { empl }\end{array}$ \\
\hline Maintenance & 2 & Maintenance & 0 \\
\hline Technician & 2 & Technician & 0 \\
\hline Brewmaster & 1 & Brewmaster & 1 \\
\hline Process engineer & 2 & Process engineer & 1 \\
\hline $\begin{array}{l}\text { Warehouseman } \\
\text { products }\end{array}$ & 1 & Warehouseman products & 1 \\
\hline $\begin{array}{l}\text { Row material } \\
\text { warehouse }\end{array}$ & 2 & Row material warehouse & 1 \\
\hline Maintenance manager & 1 & Maintenance manager & 0 \\
\hline Administration & 2 & Administration & 2 \\
\hline Economic departement & 2 & Economic departement & 1 \\
\hline Gate-keeper & 4 & Gate-keeper & 0 \\
\hline Building management & 0 & Building management & 1 \\
\hline Manipulation worker & 0 & Manipulation worker & 1 \\
\hline Purchase department & 2 & Purchase department & 0 \\
\hline Total & 21 & Total & 9 \\
\hline Source: author processing & & \\
\hline
\end{tabular}

Source: author's processing

Table 5: Other professions.

\section{Additional important comparation}

By comparing the efficiency of old and new technology of production and bottling of beer, the author came to the conclusion that the new technology shows substantial savings in production and operating costs (Table 6).

\begin{tabular}{|l|c|c|}
\hline Indicators & Old equipment & New equipment \\
\hline Water consumption & $61 / 1$ liter beer & $31 / 1$ liter beer \\
\hline $\begin{array}{l}\text { Loss in production } \\
\text { carelessness }\end{array}$ & $15 \%$ & $2 \%$ \\
\hline $\begin{array}{l}\text { Loss in production intentional } \\
\text { (Fraud) }\end{array}$ & $30 \% !$ & $1 \%$ \\
\hline $\begin{array}{l}\text { Constant deviation of beer } \\
\text { quality }\end{array}$ & $10 \%$ & $0.40 \%$ \\
\hline Frauds elimination & $20 \%$ & $97 \%$ \\
\hline $\begin{array}{l}\text { Work productivity possibility } \\
\text { control }\end{array}$ & $30 \%$ & $90 \%$ \\
\hline
\end{tabular}

Source: author's processing

Table 6: Economic indicators.

Comparison of annual energy savings and wage costs in thousands of CZK

Table 7 compares savings on selected cost items. The presented result shows considerable annual savings in production, which will significantly reduce the price of beer while maintaining its quality. I made a comparison of cost savings in a selected beer production company on selected annual reporting data and on the basis of extracted data from the original technology analysis and new technologies presented in Tables 1 to 5 .

\begin{tabular}{|l|c|c|c|}
\hline Position & $\begin{array}{c}\text { Old } \\
\text { technology } \\
\text { in ths. CZK }\end{array}$ & $\begin{array}{c}\text { New } \\
\text { technology } \\
\text { in ths. CZK }\end{array}$ & $\begin{array}{c}\text { New technology } \\
\text { savings } \\
\text { in ths. CZK }\end{array}$ \\
\hline Energy & 37990 & 24623 & 13367 \\
\hline Personal expenses & 14087 & 5122 & 8965 \\
\hline
\end{tabular}

Source: author's processing

Table 7: Selected data of real beer production enterprise.

Robotic internal audit in the context of the agriculturals businesses

The current trend in agriculture is to increase farmers' productivity by using automated systems Yang et al, 2018; Comba et al., 2010), robotic machines (Akbarzadeh et al., 2013; Richards et al., 2015) (transport vehicles) (Sorensen et al., 2004), guided and navigated GPS (Ball et al., 2015), robotic milking systems, robotic fruit harvesting machines, vines, etc.

The global food chain is facing population growth, climate change, water loss in nature, as well as political pressures. Robotics, automatic systems, and digital technology help to transformation of agriculture and food industry. Research in this area helps to plan, coordinate, manipulate and interoperate 
between robots and the human control factor (Trianni et al, 2018). The global agri-food industry could be transformed by the implementation of robotics and digital advanced industrial systems 4.0 (Barth et al, 2014). These sophisticated systems can attract qualified IT professionals.

Manufacturing and agriculturals are closely interconnected. Agriculturals businesses produce commodities that are essential for food production as well as beer production. It is therefore necessary for agriculturals businesses to produce a commodity at a price that is competitive on the market. An important aspect is therefore the reduction of production and sales costs. Robotic internal audit can also be applied to agriculturals businesses. The theme of internal audit in the conditions of the agriculturals businesses, was dealt with by an author, Rímovská (2001), in an article in Agris magazine. It focused on risk analysis and management. This means the consistency of documents with the real state of the agriculturals businesses. She found that only $20 \%$ of farms have managed risk management. Another author, who was dealt in internal auditing in agriculturals businesses, is Čapek ${ }^{7}$, who, in his presentation under the aegis of the European Agricultural Fund for Rural Development, devoted himself to regular procedures and procedures in the framework of a regular internal audit. One of the nonconformities referred to by the author in the internal audit is insufficiently secured crossings between the zones, low frequency of waste handling, unsecured sanitation, lack of integrity control, poorly stored raw materials and products, unsystematic maintenance of machinery and machines needed for production. All of these findings can be identified as the cause of technological and other production losses. There is losses in storage as well as possible failure of human factor - fraud. All of these aspects are closely linked to accounting that may be distorted by these losses and the financial statements do not faithfully reflect the state of the assets and liabilities in contravention of accounting and tax regulations.

\section{Results and discussion}

\section{Evaluation of the main objectives}

Detecting risk spots in the enterprise management process and in production process to identify fraud opportunities is a prerequisite

\footnotetext{
7 Čapek, T. (year is not listed) Available: www.uniconsulting.cz/ download/ucebnitext/Interni_auditor_kvality_potravinarstvi.pdf [Accessed 30 Oct. 2018].
}

for streamlining production and savings in the cost area. The calculation of production and causally related operating costs is closely related to financial accounting, which may be distorted by the embellishment of beer production results. In the Czech Republic, financial accounting is very closely linked to the tax base and other taxes. If a robotic internal audit is not implemented and implemented in manufacturing plants, which can detect fraud in both production, and accounting in real time, there may also be losses in income tax, VAT and excise duty.

Comparing of the value of the old technology where is not applied internal audit and new automated technology where is robotic internal audit included is clear that strategic investment of corporation to new production technology for foods or to agriculturals technology save significant production costs and in particular financial resources for faster return of investment. Corporate management obtain all information and values of productivity and efficiency of beer production from robotic internal audit in real time. A new fully automated technology can be clasified as anti-fraud technology, that the performance of the automated process of production and beer bottling minimizes human factor failure. If fraud occurs in the manufacturing process, corporate management obtain all information about this case in real time, not than after the current monthly financial statement.

\section{Discussion}

Fraud management can also be applied in a modern farm management system. Its function is to eliminate all losses caused by human factor failure and technological losses, using robotization of internal audit. Every upgrading and innovation within the business requires the development of strategic plans, including a plan for new modern investments that allow the installation of control devices to prevent losses on the agriculturals enterprises. An integral part of fraud management is an information business system that allows sharing and reporting data to a data warehouse for further fraud management. The application of robotic internal audit is specific for each production and farming enterprise, but for some production and production processes, similar control measuring devices can be applied. For example, barcode readers, process scales, level gauges, flowmeters, ect.

The main objective of the Czech Republic's Rural Development Program, approved by the European Commission, is the restoration and improvement 
of agricultural dependent ecosystems, in particular agro-environmental measures, and investment in competitiveness and innovation of agricultural enterprises. The Ministry of Agriculture of the Czech Republic has earmarked EUR 3.5 billion for this program from European and national sources. Therefore, there is time to create strategic plans for the modernization of the farm management system with the support of robotization, automation and digitization.

\section{Conclusion}

The article is focused on the implementation of robotic internal audit in the process of industrial beer production. The main objective of the RPA implementation is to streamline production, reduce production and operating costs in production and prevent fraud opportunities in the manufacturing plant.

On the basis of the comparison of the energy and personnel demands of the old and new technology of production and bottling of beer into PET bottles, performed in tables 1 to 7 , significant cost savings have been demonstrated. In the energy sector, the saving is $46.5 \%$ in the wine and $27.48 \%$ in the bottling line, which represents an annual saving of 13,367 thousand. CZK. Savings in the area of personnel and wages are

Corresponding authors

Ing. Marcela Hradecká

Department of Accounting and Finances, Faculty of Economics

University of South Bohemia, Studentská 13, 370 05, České Budějovice, Czech Republic

Phone: +420 602346 483, E-mail: hradecka@mh-dane.cz

\section{References}

[1] ADB Automatic devices of the brewery (2018) "Control equipment", Marco Bortolan, Jan. 2018. [Online]. Available: www.marcobortolan.it [Accessed: 31 Sep. 2018].

[2] Akbarzadeh, N. A., Bazargani, S. S. B., Yaghoubi, S., Bamizan, M., and Asl, M. I. (2013) "Autonomous Robots for Agricultural Tasks and Farm Assignment and Future Trends in Agro Robots", International Journals of Machanical \& Mechatronics Engineering IJMME-IJENS, Vol. 13, No. 3. ISBN 134301-1303-8989.

[3] Ball, D., Ross, P., English, A., Patten, T., Upcroft, B., Fift, R., Sukkarieh, S., Wyeth, G. and Corke, P. (2015) "Robotics for Sustainable Broad-Acre Agricultural", Result of the $9^{\text {th }}$ International Conference "Field and Service Robotics", Queensland University of Technology Brisbane, Australia. ISBN: 978-3-319-07488-7. DOI 10.1007/978-3-319-07488-7_30.

[4] Barth, R., Baur, J., Buschmann, T., Edan, Y., Hellstrom, T., Nguyen, T., Ringdahl, O., Saeys, W., Salinas, C. and Vitzrabin, E. (2014) "Using ROS For Agricultural Robotics Design Consi Derations and Experiences", Conference RHEA, Madrid. Spain. ISBN 978-84-615-6184-1. less than 6 employees less, and 7 employees by 12 serving the bottling line other staff saving of CZK 8,965 thousand.

described as the elimination of theft of input commodities, semi-finished products and finished products and then eliminating the losses caused departments. A fully automated production human resources and minimizes wastefulness. and thus the acceleration of the return on investment.

Analyses and outputs from the robotic internal audit enable the efficient cash flow planning of operational and investment character, well as effective planning of the value growth of the production enterprise. enterprises, along with the modification of Czech Republic in the ranking of ranking by several ranks higher. Another advantage of this automation and robotic

Automation and robotization of industry 4.0 
[5] Comba, L., Gay, P., Piccarolo, P. and Ricauda, A. D. (2010) "Robotics and Automation for Crop Management: Trend and Perspective", International Conference Ragusa SHWA "Work Safety and Risk Prevetion in Agro-Food and Forest Systems", Radusa Ibla Campus, Italy. ISSN 2532-103x.

[6] Čapek, T. (year is not listed) "Interní audit při výrobě krmiv a výkupu zemédělských produktü" (Internal audit in food production and purchase of agricultural products). [Online]. Available: http:// www.uniconsulting.cz/download/ucebni-text/Interni_auditor_kvality_potravinarstvi.pdf [Accessed 30 Oct. 2018]. (In Czech).

[7] Danos, P., Eugene, A. and Inhoff, Jr. (1992) "Financial Accounting“", Boston, University of Michigan, pp. 347-379. ISBN 0-256-06187-4.

[8] Dovenport, J. and Ralphael, J. (2018) "Creating a Cognitive audit". [Online]. Available: https://www2.deloitte.com/content/dam/Deloitte/us/Documents/audit/us-audit-creating-cognitiveaudit.pdf [Accessed: 31 Mar. 2019].

[9] Grimstad, L., Phan, H. N. T., Pham, C. D. Pal, J. and Bjugstad, N. (2015) "Initial field-Testing of Thorwald a Versatile Robotic Platform for Agricultural Applications", Norwegian University of Life Sciences. Norway, Conference IROS, workshop on Agri-Food Robotics.

[10] IFI Intelligent factory of 4.0 industry (2018) "SWM supervisor functions“, SMI, Jan. 2018. [Online]. Available: https://www.smigroup.it/profilo/line-supervisor-swm [Accessed 31 Sep. 2018].

[11] Kabeš, K. (2015) "Robotika v zemědělství je na vzestupu" (Robotics in agriculture in in increase), Automa, No. 2. ISSN 1210-9592. (In Czech).

[12] Kavan, M. (2002) "Výrobní a provozní management" (Production and Operational Management), Prague, Grada Publishing, pp. 159-208. ISBN 80-247-0199-5. (In Czech).

[13] Korecký, M. and Trkovský, V. (2011) "Management rizik projekti̊ se zaměrením na projekty v průmyslových podnicich" Management of risks with focus on projects in insustrial enterprises), Prague, Grada Publishing, pp. 439-475. ISBN 978-80-247-3221-3. (In Czech).

[14] Král, B. (2008) "Manažerské účetnictví“ (Managerial accounting), Prague, Managemnt Press, pp. 299 -303. ISBN 978-80-7261-141-6. (In Czech).

[15] Myers Brigs, I. (1980) "The Myers-Briggs type indicator MBTI". [Online]. Available: https://www.capt.org/mbti-assessment/isabel-myers.htm?bhcp=1 [Accessed $31 \quad$ Sep. 2018]. DOI 10.1007/978-3-319-28099-8_50-1.

[16] Network (2017) [Online]. Available: https://www.pwc.com/us/en/risk-assurance/publications/ assets/pwc-robotics-process-automation-a-primer-for-internal-audit-professionals-october-2017. pdf [Accessed: 31 Oct. 2018].

[17] Pospíšilová, M., Mejzlík, L. and Velechovská, L. (2008) "Počitačem intergované ř́zení podniku“ (By computer managed business), Prague, Bova Polygon, pp. 131-155. ISBN 978-80-7273-153-4. (In Czech).

[18] Richards, S. D., Patten, T. Fitch, R. Ball, D. and Sukkarieh, S. (2015) "User Interface and Coverage Planner for Agricultural Robotics", Australasian Conference on Robotics and Automation, ACRA, Quensland University of Technology, Australia. ISBN 978-0-9807404-6-2. ISSN 1448-2053.

[19] RPA Robotic Process Automation (2017) "A primer for internal audit Professional“. PwC.

[20] RPA Internal Audit and Robotic Process Automation (2018) „KPMG Advisory N.V.“ [Online]. Available: https://assets.kpmg/content/dam/kpmg/nl/pdf/2018/advisory/internal-audit-and-roboticprocess-automation.pdf [Accessed: 15 Nov. 2018].

[21] Ř́movská, P. (2001) "Aplikace formalizovaných modelů identifikace a hodnocení rizik v podmínkách zemědělských podniků". [Online]. Available: www.agris.cz [Accessed 30 Oct. 2018]. 
[22] Sorensen, C. G., Bak, T. and Jorgensen, R. N. (2004) "Mission Planner for Agricultural Robotics", Danish Institute of Agricultural Engineering Research Centre Bygholm. Denmark.

[23] Synek, M., Kislingerová, E. (2010) "Podniková ekonomika“ (Business economics), Prague, C. H. BECK, pp. 369-379. ISBN 978-80-7400-336-3. (In Czech).

[24] Smejkal, V. and Rais. K. (2013) "Řizení rizik ve firmách a jiných organizacích" (Risk Management in firms and other organizations), Prague, $4^{\text {th }}$ ed., Grada Publishing, $134 \mathrm{p}$. ISBN 978-80-247-4644-9. (In Czech).

[25] Trianni, V., Ijsselmuiden, J. and Haken, R. (2018) "The SAGA Concept: Swarm Robotics for Agricultural Applications", Conference IROS Madrid, Spain. [Online]. Available: www.echord. eu/saga/. [Accessed 31 Sep. 2018].

[26] Ducket, T., Pearson, S., Balckmore, S. ... Yang, Z. G. (2018) "Agricultural Robotics: The Future of Robotic Agriculture", UK-RAS Network White Papers. ISSN 2398-4414. 